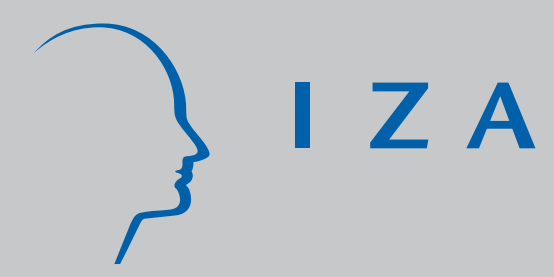

IZA DP No. 1432

Are There Gender and Country of Origin Differences in Immigrant Labor Market

Outcomes across European Destinations?

Alicia Adsera

Barry R. Chiswick

December 2004 


\title{
Are There Gender and Country of Origin Differences in Immigrant Labor Market Outcomes across European Destinations?
}

\author{
Alicia Adsera \\ University of Illinois at Chicago, \\ University of Chicago and IZA Bonn \\ Barry R. Chiswick \\ University of Illinois at Chicago \\ and IZA Bonn \\ Discussion Paper No. 1432 \\ December 2004
}

\author{
IZA \\ P.O. Box 7240 \\ 53072 Bonn \\ Germany \\ Phone: +49-228-3894-0 \\ Fax: +49-228-3894-180 \\ Email: iza@iza.org
}

\begin{abstract}
Any opinions expressed here are those of the author(s) and not those of the institute. Research disseminated by IZA may include views on policy, but the institute itself takes no institutional policy positions.

The Institute for the Study of Labor (IZA) in Bonn is a local and virtual international research center and a place of communication between science, politics and business. IZA is an independent nonprofit company supported by Deutsche Post World Net. The center is associated with the University of Bonn and offers a stimulating research environment through its research networks, research support, and visitors and doctoral programs. IZA engages in (i) original and internationally competitive research in all fields of labor economics, (ii) development of policy concepts, and (iii) dissemination of research results and concepts to the interested public.
\end{abstract}

IZA Discussion Papers often represent preliminary work and are circulated to encourage discussion. Citation of such a paper should account for its provisional character. A revised version may be available directly from the author. 


\section{ABSTRACT \\ Are There Gender and Country of Origin Differences in Immigrant Labor Market Outcomes across European Destinations?*}

The paper uses the 1994-2000 waves of the European Community Household Panel to conduct a systematic analysis of the earnings of immigrants as compared to native workers, in particular to test whether there is any systematic variation in the labor market performance of immigrants across gender related to duration in the destination, schooling, age at immigration, country of origin, or country of destination. We find a significant negative effect of immigrant status on individual earnings of around $40 \%$ at the time of arrival in the pooled sample, although the difference is somewhat smaller for women. Those differences, however, vary greatly across countries with migrants in Germany and Portugal faring best relative to natives, and those in Sweden, Denmark, Luxembourg or Spain the worst, particularly among non-EU born migrants. Gender differences are more important among those born outside the European Union, with women doing relatively better than men. Among men, those from Asia, Latin-America and Eastern Europe receive the lowest earnings. LatinAmerican and Eastern European women are at the bottom of the women's distribution. Earnings increase with duration in the destination and the foreign born "catch-up" to the native born, others variables being the same, at around 18 years in the destination among both men and women. Education matters more for women in terms of explaining earnings, whereas language skills are relatively more important for men.

JEL Classification: J1, J61, F22

Keywords: immigrants, earnings, gender, countries of birth and destination, language

Corresponding author:

Alicia Adsera

Department of Economics

University of Illinois at Chicago

601 S. Morgan St.

Chicago, IL 60607

USA

Email: adsera@uic.edu

\footnotetext{
* We appreciate comments received from participants at the 2004 Midwest Economics Association Annual Meetings, and the financial support provided by the Graduate College Research Board, University of Illinois at Chicago as well as University of Illinois Institute of Government and Public Affairs and the Grant Numbers P30-HD18288 and T32-HD007302 from the NICHD. Its contents are solely the responsibility of the authors and do not necessarily represent the official views of the authors affiliations or the $\mathrm{NIH}$.
} 


\section{Are There Gender and Country of Origin Differences in Immigrant Labor Market Outcomes across European Destinations?}

\section{Introduction}

Immigration has become an important socioeconomic and public policy issue in all of the highly developed economies. Western Europe, which used to think of itself as a region of emigration, has experienced substantial net in-migration in the last four decades from the lesser-developed countries and in the last decade from the former Eastern bloc countries. Understanding how well immigrants from different origins adapt to diverse labor markets across Europe and whether labor market outcomes, such as earnings, occupation or unemployment among immigrants, differ by gender is central to any policy recommendation.

The European Community Household Panel (ECHP) is the first household survey that provides the data necessary for a comparative analysis of the adjustment and impact of immigrants, not only across broad geographic areas of origin but also across the European destination countries. This paper uses the 1994-2000 waves of the ECHP to conduct a systematic analysis of individual earnings from work among immigrants as compared to native-born workers. It is particularly interested in analyzing whether there is any systematic variation in the labor market performance of immigrants across the genders related to duration in the destination, schooling, age at immigration, country of origin, or country of destination.

The structure of the paper is as follows. Section 2 provides a brief review of the literature on immigrants' earnings in developed countries and comparisons of gender 
differences in immigrant outcomes. Section 3 introduces the data and the statistical methodology. Section 4 discusses the results and section 5 concludes the paper.

\section{Background}

Research on the labor market adjustment of immigrants in the destination economy began with Chiswick's (1978) analysis of "The Effect of Americanization on the Earnings of Foreign-Born Men.” Using the 1970 Census of Population, this study found, among other findings, that for adult white men earnings were higher among immigrants in the United States a longer period of time, other measured variables being the same. Moreover, although initially having lower earnings, immigrants in the U.S. around 13 years had reached earnings parity with the native born, after which they have higher earnings.

This was followed by a study for the U.S. of male immigrants of all races and ethnicities from all countries of origin (Chiswick 1979). This study also found the earnings catch-up in the 10 to 20 year period when race/ethnic origin among immigrants is the same as the native born. Yet, compared to the native born as a whole, immigrant earnings differed by race/ethnicity.

These analyses were quickly followed by a study of white immigrant women in the United States by Long (1980) to test the robustness of the findings for men. Using the 1/1,000 sample from the 1970 Census, as did Chiswick (1978), Long shows that unlike the finding for men, there is no statistically significant effect on immigrant women's earnings of duration in the United States. 
Chiswick (1980, Chapter 9), however, showed that when the 1/100 sample is used duration is statistically significant for women, pointing to the importance of sample size in the analyses of immigrant earnings, particularly among women. Chiswick (1980, Chapter 9) did the analyses for women separately by race/ethnic group (white, black, Mexican, Cuban, and several Asian groups) and found the tendency toward the positive effect of duration in the US for most race/ethnic groups and that parity in earnings with their native-born counterparts comes sooner than for men. He also developed an algorithm for identifying Asian "war brides" and found that Asian "war brides" had lower earnings than otherwise comparable immigrant women from Asia.

During this same period, Mincer (1978) analyzed "Family Migration Decisions.” In particular, Mincer was concerned with viewing the migration decisions in two-adult families as being jointly determined. There are not only movers and stayers, but also "primary movers" and "tied movers," and "primary stayers" and "tied stayers." The "tied" spouse moves or does not move on the basis of what maximizes family earnings rather than that individual's earnings. This would put tied movers in a less favorable economic position than otherwise comparable foreign-born or native-born women.

Tied status effects earnings, labor supply and unemployment among both tied stayers and tied movers, who are disproportionately women. Tied movers, in particular, are more likely to be unemployed or out of the labor force and have lower earnings than otherwise comparable immigrant women who are primary movers.

Although most of the research on migrant labor market adjustment since then has focused on men, substantial research has been undertaken on immigrant women's labor supply, including the family investment model (Baker and Benjamin 1997). The family 
investment model hypothesizes that in the early post-migration period wives are working in the labor market rather than investing in their own destination-specific (or local) human capital so as to finance the investment in destination-specific human capital of their immigrant husbands. This would have the effect of raising the initial earnings but flattening the earnings-duration profile of immigrant women, especially if they never make these human capital investments.

Female tied movers may experience two offsetting effects on their labor supply. Given that they are tied movers, they are likely to have poorer labor market opportunities than female primary movers, and hence are likely to have a lower earnings potential and lower labor supply. On the other hand, the family migration model suggests that they will work more in the early years in the destination to finance their husband's human capital investment. Although the literature has been somewhat ambiguous as to which effect is stronger, recent research on Australian longitudinal data in which visa category can be used to identify with greater precision "primary" and "tied" movers suggests that the response to their own opportunities dominates the family investment model hypothesis for explaining immigrant female labor supply behavior (Le 2004).

In a recent study, Antecol (2000) analyzed whether gender differences in labor force participation rates of immigrants in the U.S. are related to what she refers to as ethnic or cultural differences. That is, other variables the same, she finds that gender differences in labor force participation in the US across immigrant groups from different countries of origin are significantly positively related to gender differences in the origin country. A similar, but much weaker pattern is found among second-and-higher- 
generation immigrants in the US, suggesting an assimilation to the economic incentives and cultural norms in the US.

This study builds on the existing literature but takes a different approach. The focus is on the analysis of the earnings of both immigrant men and women, the latter being a topic that has received too little attention. ${ }^{1}$ It does not consider immigrants in a destination of the same gender, age and years of schooling as homogeneous, but rather focuses on the differences by country of origin, and hence on differences by race and ethnicity. Furthermore, unlike the standard literature on the adjustment of immigrants that focuses on one destination at a time, this study emphasizes the comparison across destination countries, as well as across countries of origin. Moreover, while the literature on immigrant adjustment is dominated by research on the English-speaking countries of overseas settlement (i.e., the U.S., Canada and Australia), the analyses in this study focus on Western Europe, a region that in the past few decades has changed from a major source to a major destination for international migrants.

\section{Data and Methodology}

The paper uses the 1994-2000 waves of the European Community Household Panel (ECHP) Survey to conduct a systematic analysis of individual earnings from work of immigrants as compared to native-born workers, as well as to other immigrants from the

\footnotetext{
${ }^{1}$ Although there are exceptions, the research on female immigrants' labor market experience has focused on labor supply. In addition to the other papers cited above, see for example, Biswal (1999), Boyle, Cooke, Halfracree and Smith (2001), Cobb-Clark and Crossley (2004), Cobb-Clark and Connolly (2001), Duleep and Sanders (1993), Evans (1984), and Reimers (1985). For analyses of the earnings of female migrants see also Antecol, Cobb-Clarck and Trejo (2002), LeClere and McLaughlin (1997) and MacPherson and Stewart (1989).
} 
same country of origin in different destination countries and some different origins in the same destination. The ECHP is a unique dataset produced by the European Union Statistical Office (Eurostat), that presents comparable micro-level (person/households) data on income, living conditions, demography, migration, housing, health and work, for households across 15 European Union member states. The dataset also includes observations from the German socioeconomic household panel (SOEP), from the household panel from Luxembourg (PSELL) and from the British household panel (BHPS). Interviews in the ECHP were conducted simultaneously across all countries and data from national household panels were structured to mimic the rest of the ECHP. Thus, the European Community Household Panel (ECHP) is the first household survey that provides the data necessary for a comparative analysis of the adjustment of immigrants not only across broad geographic areas of origin, but also across the major European destination countries.

The natural logarithm of individual earnings in purchasing power parity (PPP) terms is analyzed both in a pooled sample and in a fixed-effects model. Earnings are measured as total net income from work. Income data for France and Finland are in gross terms instead of net terms and this needs to be taken into account in interpreting results. The ECHP sample contains around one million observations for individuals from the 15 European Union countries, but only just over half of them work and report income from work.

After all explanatory variables are included, thereby deleting cases with missing values, the sample consists of 547, 639 observations on individuals aged 18 and older- 
231,457 women and 316,182 men. ${ }^{2}$ Table 1 presents the distribution of observations, individuals of foreign birth and the percentage born in other European Union nations across destination countries. Foreigners represent 5.1 percent of the sample used in this study. ${ }^{3}$ Among foreigners, around 46 percent of those in the sample are citizens of other European Union countries. In Table 1A in the Appendix, the proportion of EU-born among migrants in the final sample is compared to that of the general population of migrants -working or not working. The proportions are quite stable for most countries, except for the Netherlands where, due to missing observations for some variables, the proportion of EU-born increases from $62 \%$ of the foreign population to $95 \%$ in the sample, and for the UK and Portugal where the proportions of EU-born in the sample decrease from $52 \%$ to $28 \%$ and from $39 \%$ to $29 \%$, respectively.

The explanatory variables included in the analyses are:

1. Marital Status is measured by including two variables, one for currently married (Marry=1) and another for cohabitation (Union=1). As a result, single and not cohabiting is the omitted category. Marriage is expected to be associated with lower earnings for women and moderately higher earnings for men to the extent that a division of labor in the household has a different effect by gender on past labor supply and work effort.

\footnotetext{
${ }^{2}$ Even if some individuals appear repeatedly in different years, observations are taken to be independent.

${ }^{3}$ Some of the covariates are missing more frequently for foreign-born individuals than among natives. Table A1 in the Appendix presents data for Table 1 if the years since migration variable, a variable with a higher rate of missing values, were not included in estimates. Note that the percentage of foreign-born increases to $6.64 \%$ of the sample and Luxembourg, the UK and the Netherlands experience the largest changes in sample size.
} 
2. N. Children. The number of children present in the household is also included in the estimates. This variable is expected to have a negative impact on women's earnings and a positive one on men's earnings.

3. Education. The education or the student status of the individual at the time of each interview is available. The educational categories are less than upper secondary (Less Secondary=1), upper secondary (the omitted category) and at least some tertiary education (Tertiary Educ. =1). Unfortunately, a continuous variable for education, such as years of schooling, is not available.

4. Experience (Yrs Experience \& Sq. Experience). The survey reports the year when the individual worked for the first time. However, two considerations are warranted: first, data are not available for Sweden, and, second, on many occasions some of the reported answers are not consistent with responses to other questions in the survey. To create a more systemic and perhaps less error-prone measure of experience, information on completed levels of education is used as follows: Potential experience is constructed as the age of the individual minus 14, 18 or 23 years depending on the highest level of schooling (Age minus years of schooling minus six years). This measure of experience and its square are used in this study. ${ }^{4}$

5. Foreign Birth (Foreign=1). A variable is included to denote that an individual was foreign born. The ECHP includes several pieces of information on the migration

\footnotetext{
${ }^{4}$ Similar regressions were also computed using experience as calculated by age minus the reported age at first job. In cases where information was missing the constructed measured of experience, described in the text, was used instead. These two measures are highly correlated. The results do not vary with the measure of experience and are available from the authors by request.
} 
trajectory of each person surveyed. Since some questions were censored in the data for some countries, different data items are combined to construct this variable. This includes information on whether the person was foreign born (not readily available for Germany, part of Luxembourg and Sweden); whether they were born in the European Union or not (not available for Greece, the Netherlands and the ECHP sample of Germany); and on their citizenship.

6. Years since Migration (Yrs. since Migr. \& Sq. YSM). This variable is constructed from the year of arrival in the country of present residence. Unfortunately, as shown by comparing Tables 1 and A1 there were a few missing observations for this question. The square of years since migration is also included to reflect the nonlinear effect on income of duration in the destination.

7. Geographic Area of Origin. This variable distinguishes between those born within the European Union or outside it. For Germany, the Netherlands, Greece, Finland and the PSELL sample from Luxembourg this is the only information available on the foreign country of birth. Information on the continent of origin is also available for all the other countries - Europe, Africa, Asia, America and Oceania. As a result, when all the continents are included as explanatory variables, the coefficient for those born outside the European Union corresponds to individuals from “other European origins”, mostly Eastern Europe. Where data on continents is available, except for those living in Italy and Austria, Americans can be divided into North and South/Central America. A variable for Non-English Americans is created that includes all persons classified as South- Central American, as well as those whose mother tongue is not English. Thus Mexicans are in the non-English 
American group. Individuals for whom we do not have information either on language or on continent are excluded from the sample when using continents as variables in the analysis.

8. Language Spoken. The variable "mother tongue" is not available for the UK, Sweden and the Netherlands and is only available for the other countries in the year 2000 ( $7^{\text {th }}$ wave). Using the identification code of the individual, a mother tongue variable is created for other waves when the individual is present both in the $7^{\text {th }}$ wave and previously. Two variables with language information were created. Same Language $=1$ if the language of the migrant and that of the country of destination match. Group Language $=1$ when the linguistic group of the language from the country and the migrant's match, that is they are close languages. The language groups are Romance (French, Portuguese, Spanish, Italian), English, Nordic (Danish and Swedish) or German/Dutch. Greek and Finish are considered two separate language groups. In Luxembourg and Belgium both the Romance and Germanic language groups are accepted. Individuals for whom language information is not available are not included in the analysis when language variables are used.

Models are estimated with and without country of destination dichotomous variables. Further, foreign origin and birth outside of the European Union are also interacted with country of destination to determine whether the effects on earnings of foreign birth in and outside the EU differ across the 15 destination countries. The next section presents only the more complete estimates and discusses the rest of the findings. 


\section{Results}

\subsection{The effect of foreign origin across gender}

To study the effect of foreign birth, the natural logarithm of individual earnings from work net of taxes (in PPP terms) is analyzed both in a native-foreign pooled sample of all destination countries and in a fixed-effects model, with and without interactive variables between foreign birth and country of destination. For France and Finland, however, the earnings data are in gross terms. Welfare provisions such as housing and day-care subsidies, guaranteed income, unemployment benefits and others vary greatly across Europe and tend to be very generous in Nordic countries. Consideration of the effects of these sources of income and their effects on net earnings are beyond the scope of this study.

In a pooled sample, the earnings of foreign women and men at the time of arrival are estimated to be around $38 \%$ and $42 \%$, respectively, lower than those of natives. When foreigners are split among those born in the European Union and those born outside it, the EU-born women and men only experience 33\% lower earnings at arrival with respect to natives, whereas women and men born outside the EU have around 41\% and 56\% lower earnings than natives, respectively. When both destination country dummies and interactive variables of foreign birth with destination country are included, coefficients on foreign birth portray a great variance among destination countries. Differences in earnings of immigrants relative to natives of the same gender in each country vary from a low of $8 \%$ for women and $19 \%$ for men living in Germany, to a high of $62 \%$ and $67 \%$ for foreign women and men living in Sweden. 
Table A2 in the Appendix includes the most complete specification with destination country dummy variables and interactive variables for destination country with both foreign birth and birth outside of EU. Tables A3 and A4 in the Appendix present simulated log earnings of an individual who has 10 years of experience, a high school diploma, is married and has one child. Table 2 presents simulated differences in earnings of foreigners from the EU and from outside the EU as a percentage of the earnings of natives of the same gender in each destination country. Significance levels for coefficients on foreign birth are included. The third and sixth columns include the significance level at which earnings from EU and non-EU migrants in each destination country differ. The coefficient -0.204 for foreign men in Belgium means that men born outside Belgium earn about 20\% less than men born in Belgium at arrival, other variables the same. The coefficient -0.459 for those born outside the EU means that, at arrival, they earn about $46 \%$ less than men born in Belgium, other things equal. ${ }^{5}$ The entry in the third column indicates that there are significant differences between the earnings of foreign men in Belgium who were born in another country of the EU and those who were born outside the EU.

Individuals born in the European Union but living in another European country have significantly lower earnings at arrival than natives in all cases, except for women in Germany. Among foreign men born in the European Union differences relative to native men are only on the order of 15\% for those living in Germany, the UK and Portugal, but the differences are much larger (up to 50 to 60 percent) for those living in Luxembourg, Ireland, Spain and Finland. For EU-born women, except for those in Germany whose

\footnotetext{
${ }^{5}$ The percent difference in earnings (b) equals $\exp \left(b^{*}\right)-1$ where $b^{*}$ is the regression coefficient. $\mathrm{B}$ is approximately equal to $\mathrm{b}^{*}$ only when $\mathrm{b}$ is small.
} 
earnings are comparable to German women, differences with respect to native women range from 22\% (UK) to 62\% (Finland) but are more homogenous than those for men. The UK is the "best" destination after Germany for that group of women. Countries where the relative earnings at arrival of the EU-born are the lowest with respect to their native counterparts, over 50\% lower, are Finland, Ireland, Luxembourg and Spain for men and Finland, Luxembourg, Sweden and Italy for women.

The earnings of migrants born outside the EU are significantly lower at migration than the EU-born in 6 of the 15 of the countries presented in Table 2. Sweden is the country where the differences are the greatest and most highly statistically and economically significant overall. A man born outside the European Union earns around 82\% less than a Swedish man at migration and a non-EU-born woman around 70\% less than a Swedish woman. The earnings differences of these individuals with respect to migrants from the EU living in Sweden amount to $42 \%$ and $20 \%$ for men and women at migration, respectively. The UK and Spain are the other countries where differences between the two groups of foreign workers (EU and non-EU) are significant and relatively sizable both for men and women. In Spain those differences amount to $26 \%$ for women and $15 \%$ for men. In the UK the numbers are 16\% and 37\%. Men from outside the EU in Belgium earn 25\% less than their EU counterparts -a group that includes many EU bureaucrats- and those in France 9\% less.

Interestingly, for non-EU men in Ireland and non-EU women in Austria earnings are higher than those of migrants from EU countries. In Ireland most of those immigrants are from the US and Canada and in Austria they arrive mainly from the former Soviet 
Union. Around 77\% of migrants to Austria are from outside the EU and Austria hosts a quarter of all Non-EU European migrants in the sample.

To sum up, differences vary greatly across countries, with migrants in Germany and Portugal faring the best earnings situation relative to natives and those in Sweden, Denmark, Luxembourg and Spain the worst -particularly among those not born in the EU.

Table 3 presents simulated differences in earnings of foreigners at arrival in different countries as compared to those arriving in Germany. Thus, Germany is the benchmark with a value zero and all the other values in the table represent percentage deviations from German earnings. For example, the coefficient -0.097 for Danish native men means that men born in Denmark earn about 9.7\% less than men born in Germany, other variables the same.

Among native men and women, earnings are the highest in Luxembourg. The existence of a large community of people working for the European Union institutions who enjoy very high salaries may explain the Luxembourg pattern. The same reasoning applies also when the earnings of foreigners are compared across countries, particularly among EU-born migrants. Foreigners in Luxembourg have the highest earnings of all. Nonetheless a close look at the composition of EU migrants in Luxembourg shows that there are both conventional economic migrants -mostly from Portugal- and those who work for the EU administration. Differences with the other countries narrow when only the non-EU group is examined. In any case, only around 10\% of migrants in Luxembourg come from outside the EU and these are mostly from Eastern Europe. 
Setting aside Luxembourg, among EU-born foreign men, those living in the Netherlands, the UK, Austria and Germany receive the highest earnings. Among foreign EU women, Germany is by far the best destination, followed by Austria, Ireland, Denmark, Italy and the UK - countries where foreign EU women typically earn around a quarter less than their counterparts in Germany. Sweden and Finland are the countries where the foreign EU-born have lower net earnings compared to those living in Germany, over two thirds less.

Earnings among foreign men born outside the European Union are, again, much lower in Nordic countries (Denmark, Sweden and Finland) and Spain in comparison to those in Germany where they fare the best. Earnings in Ireland and Austria follow closely those in German. Later we show that in the case of Ireland this may be traced to the particular composition of its immigration pool that contains a large proportion of men born in North America. Earnings for foreign women born outside the EU are more homogeneous across countries than those of men. Austria, the Netherlands and Germany are the best destinations, followed closely by France, Italy and Portugal. The lowest earnings for the group are found in Sweden and Ireland.

\subsection{Gender differences in demographic variables.}

The focus of the paper is to understand whether there are some underlying gender differences in the factors that explain individual earnings from work. Table 4, columns (1) and (2), include only coefficients of the demographic control variables for the general specifications employed in the paper. Columns (3) and (4) include the same set of variables as well as a language variable. Complete estimates for all specifications are 
included in the Appendix (Table A2). Interesting gender differences arise from the analysis of Table 4.

As expected, earnings increase with the level of education. Returns to education are higher for women than for men. Estimates in column (1) and (2) imply the earnings of women with tertiary education are 93\% higher than those with less than upper secondary education. Differences for the same educational groups among men are only in the order of $66 \%$. Interestingly, when the language variable is included in estimates in columns (3) and (4), differences for the same groups widen to $103 \%$ and $71 \%$, respectively. When the same regression using this restricted sample is computed, but excluding the language variable, it becomes evident that the change in the effect of education when the language variable was added is due to the change of the sample.

Years of experience in the work place - or years of potential experience, as estimated here-, have a similar effect across gender. Women double their initial earnings after 12 years of experience and men after $12 \frac{1}{2}$ years. Interestingly, if the number of children in the household is not included in the specification, the effect of experience is somewhat stronger for men than for women.

Individuals living with a spouse, whether married or cohabiting, have higher earnings than single workers. Married men earn 3 to $4 \%$ more than those in consensual unions and around 32\% more than single men. Controlling for the number of children in the household, married women earn around 7\% more than single women but around 15 to $16 \%$ less than those in consensual unions.

The number of children in the household has a strong negative effect on women's earnings of around $14 \%$ per child. Thus, while married women without children do better 
than single women without children, married mothers with one child earn $7 \%$ less than singles. For men, the coefficient on the number of children is significant and positive but negligible in size (around 1\% per child). If the number of children is excluded from the specification, married women on average earn about 3\% less than single women.

The years that have lapsed since the migrant came to the destination and the square of years since migration are included in the regression. The positive effect of time in the country of destination is slightly larger for men than for women. Overall, in the pooled estimates, coefficients are slightly larger than those in Table 4 but their combined effect in terms of the number of years required to attain the mean earnings of natives is quite similar. As noted, in the pooled regressions, foreign individuals at arrival earn around 38\% less among women and 42\% less among men than the native workers. Given the estimated coefficients on years since arrival, it takes migrants around 18 years to earn what native workers earn on average.

Table 4 presents coefficients for years since arrival when destination country variables are interacted with foreign origin and non-EU birth. The implied earnings catch-up with the native born is also around 18 for both genders. Thus, EU-born migrant men in Austria and Italy, or EU-born migrant women in Spain and France, or non-EU born migrant men in Ireland and Greece need about 18 years to reach earnings parity with the natives in their country of destination, other measured variables the same. From that table, implied earnings of non-EU born migrant men working in Germany or Portugal are equivalent to those of natives less than 10 years after arrival, and numbers are even smaller, 5 and 7 years for non-EU women migrating to those same countries. However, 
when the same specification is run separately by country, the timing of earnings convergence to natives' is extraordinarily similar (around 18 years) across countries. ${ }^{6}$

Table A5 in the Appendix presents the proportion of migrants in each country whose mother tongue belongs to the same language group as the destination country. The proportions are very high for most countries except for Germany, followed by Denmark. Around $74 \%$ of those migrating to Portugal, $45 \%$ of migrants in France and 52\% of those living in Spain speak a language in the Romance group. This arises from the propensity among migrants to move to a country where, other things the same, the cost of adjustment is lower. A smaller linguistic distance between the origin and destination languages reduces this cost (Chiswick 1998; Chiswick and Miller 1995, 1998). ${ }^{7}$

Regression estimates of earnings in Table 4, columns (3) and (4) include the variable group language. This covariate controls for whether the language of the migrant belongs to the same language group as the country of destination. The sample does not include individuals living in the Netherlands, the UK and Sweden.

The coefficient on group language is negative in pooled estimates since a higher proportion of migrants are from the same language group as the destination in countries with lower average earnings. Once countries of destination variables are included, however, a group language match provides for over a statistically significant $11 \%$ increase in earnings for migrant women and a $14.5 \%$ increase for migrant men, compared to coming from a different linguistic group.

\footnotetext{
${ }^{6}$ This is quite similar to the United States where the earnings catch-up for economic migrants is about 15 years, other measured variables the same (Chiswick 1979, 1986). ${ }^{7}$ A similar phenomenon is found in Canada where immigrants to French-speaking Quebec come disproportionately from French-speaking countries of origin.
} 
Results are very similar if a variable for an exact language match is included instead. The unexpected high proportion of exact language matches in countries such as Greece suggests a high proportion of returning families among immigrants. However, when similar regressions are computed by only considering the subset of immigrants who are not citizens, as opposed to all immigrants, the results are extremely robust for men, but language does not seem to make a difference for non-citizen women’s earnings.

\subsection{Earning differences across continents of origin}

The ECHP provides information on country of birth for broad geographic areas. Nonetheless, this still provides an opportunity to analyze whether the continent of origin is relevant for explaining earnings differences across immigrants. As noted, information on continents of origin is not available for Germany, the Netherlands, Greece and Finland. Thus, these countries are not included in the estimates. Tables 5 and A6 present data on the sample size as well as on the distribution of destination countries for migrants from each continent. The number of immigrants from Oceania is fairly small and they are mostly concentrated in the UK, Ireland and Italy. Asians are almost absent from Southern Europe. Over half of those coming from Africa choose France as their destination. The majority of them, around 85\%, are natives of former French colonies, particularly in North Africa. Among Americans, English speakers move predominantly to either the UK or Ireland, whereas those from South and Central America choose mainly Spain, Portugal and Italy.

Table 6 presents estimates for the analysis of earnings including dummy variables for destination country as well as variables for continents of origin, English America (US 
and Canada), Non-English America, Asia, Africa and Oceania. Europe is the benchmark. In the first two columns a unique coefficient for foreign origin is included, whereas in the next two columns, foreign origin is interacted with country of destination. As a result, the coefficient on foreign origin alone denotes the difference in earnings between these born in the EU and the native born in their destination. This coefficient combined with the coefficient on non-EU country of birth provides a similar measure for those born in Europe outside the European Union. The overall effect for any individual born outside Europe is obtained by adding the coefficients of the non-EU born variable and the respondent's specific continent of birth.

In pooled regressions, not reported here, the difference between foreign EU born and natives is estimated to be $13 \%$ for women and twice as much for men at arrival. Being born outside the European Union adds an additional loss of 25\%, resulting in overall differences of $38 \%$ and $54 \%$ for women and for men, respectively, compared to the native born.

When country of destination dummy variables are included in columns (1) to (2) in Table 6, the relative difference of foreign born to natives widens, whereas the difference between immigrants born inside or outside of the European Union diminishes. Incomes for foreigners born in another EU country are $33 \%$ and $48 \%$ lower at arrival than natives for women and for men, respectively. Incomes for non-EU born Europeans are $48 \%$ and $60 \%$ lower for women and for men than natives' income. Coefficients for English American are positive and sizable, but fail to reach any meaningful level of significance both when country dummy variables are included in columns (1) and (2) and in pooled estimates. Men born in South and Central America have significantly lower 
earnings than non-EU Europeans in pooled results but not when dummy variables for country of destination are included in Table 6. The concentration of Central and South American immigrants in lower income countries of Southern Europe explains why the implied gap diminishes from $17 \%$ in pooled results to only a non-significant $6 \%$ in column (2). The coefficient for Asian men is significant and the relative loss in earnings moves from $17 \%$ in the pooled sample to almost $10 \%$ when dummy variables for country of destination are included in column (2). Asian women earn over 10\% more than Eastern Europeans. The few migrants from Oceania are highly geographically concentrated - in the UK, Ireland and Italy- and are moving from one high-income to another high-income area. This may explain the highly significant positive coefficient for migrants born in that continent. Earnings for an Australian in Europe are only slightly lower $-15 \%$ for women and 3\% for men- than those of a native worker.

Finally, the strongly significant and stable coefficient -in pooled and fixed-effects estimates- for African migrants deserves some discussion. Not only do African men have about 7\% higher earnings than Eastern Europeans in column (2) but also, African women, on average, do the best after EU born foreigners. African women earnings are 30\% higher than those of Eastern European women and 14\% higher than EU-born migrants when country dummies are included in column (1) and still 26\% better when country interactive variables are also added in column (3). There are several potential explanations for this effect. First, half of the migrants from Africa in our sample live in France, and French income data in the analysis is gross and not net. Note the decline in the earnings advantage of $4 \%$ when destination country fixed effects are included in the model. Second, since most of these migrants in France were born in French speaking 
former colonies in Africa (85\% come from North Africa), their language skills provide better job opportunities, as we just discussed. Finally, the long tradition of African migration into France may provide networks to newcomers. When similar regressions are computed excluding France, the coefficient for African women goes down from 0.258 to 0.186 but remains strongly significant. In parallel, since the coefficient for non-EU born goes slightly down to -0.175, African women still earn 18\% more than Eastern Europeans and 1\% more than EU-born migrants in that sample.

Columns (3) and (4) in Table 6 presents similar results by including interactive variables for country of destination and foreign origin. The coefficients of the interactive terms provide the approximate difference of earnings between EU-born migrants at arrival and natives of each country separately. They range from a low of around minus $10 \%$ for EU-born migrants arriving to Portugal to around minus $43 \%$ and $57 \%$ for EUborn women and men arriving to Sweden. The coefficient for non-EU born is slightly higher than in columns (1) and (2) and implies a strongly significant negative effect (around 21\% for women and 18\% for men). Continent of origin coefficients on migrant men fail to reach a substantial level of significance except for those born in Oceania, who earn $40 \%$ more than Eastern Europeans on average and in some countries more than native workers. Among migrant women, those born in Oceania and Asia earn around $32 \%$ and $12 \%$ respectively more than Eastern Europeans. As noted above, even though the coefficient for African women decreases by 5 percentage points, it is still highly significant and large. English American women earn 13 percentage points more than Eastern Europeans but the coefficient is only significant at a 15\% level. 


\section{Conclusions}

This paper uses the 1994-2000 waves of the ECHP to conduct a systematic analysis by gender of individual earnings of immigrants in comparison to the native born and migrants from other countries, and across countries of destination. There is a significant negative effect of immigrant status on individual earnings of around $40 \%$ at the time of arrival in the pooled sample, although this is somewhat smaller in magnitude for women than for men. Those differences, however, vary greatly across countries with migrants in Germany and Portugal faring the best relative to natives and those in Sweden, Denmark, Luxembourg and Spain the worst -particularly among those not born in the EU. In absolute terms, however, those in Luxembourg, Germany, Netherlands and Austria have the highest earnings. Earnings for individuals born in the European Union but living in another country are only around a third lower both for men and women at arrival. Gender differences are more important among those born outside the European Union, with women doing relatively better than men.

By continent, Asian, Latin-American and Eastern European men have the lowest earnings. Latin-American and Eastern European women are at the bottom of the women's distribution.

On average, after 18 years of migration, the earnings of immigrants reach equality or parity with the earnings of natives. This is about the same as that reported in findings for the US.

Returns to education are larger for women than for men. Estimates indicate that women with a college degree earn, on average, 93\% more than high school dropouts, whereas the difference in earnings for those groups is only $66 \%$ among men. 
With regard to living arrangements, other things equal, women in consensual unions earn $16 \%$ more than married women and $23 \%$ more than singles. The presence of one child, however, reduces earnings of married women to $7 \%$ less than those of singles. Married men outperform those in consensual unions by 3\% and singles by 32\%.

Language is more relevant for men than for women. Immigrants tend to migrate to EU countries on the basis of their origin language and that of the destination especially when they speak the same language, but also if the languages are from the same language group. Earnings are higher the closer the origin language is to the destination language.

This paper has presented for the first time an analysis of immigrant earnings that focuses on differences by gender, country of origin and country of destination. It is possible to do this using the integrated set of data from the European community household Panel (ECHP) (1994-2000). Overall, immigrants in Western Europe tend to have lower earnings at arrival than those born in the destination with the earnings differential greater for those born outside the EU than for immigrant born in other EU countries. The earnings disadvantage of immigrants relative to the natives of the countries in which they live are the greatest in the Nordic countries, especially Sweden. Immigrants tend to gravitate to countries with a close linguistic and cultural background, and immigrants earn more if their origin language is the same as or close to that of the destination. There is a tendency for an earnings catch-up. The immigrant-native earnings gap narrows with duration in the destination and is closed at about 18 years duration, other measured variables the same. 
While addressing many matters, this paper also raises new issues. To what extent are the differences in the immigrant/native earnings ratios by gender in the destinations due to differences in the selectivity of immigrants from the various origins to the various destinations? To what extent do differences in the transferability of skills across origins and destinations play a role? To what extent do differences in the destinations in terms of flexibility in labor markets, public assistance to immigrants, receptivity to immigrants, and discrimination play a central role? These are issues that warrant further research. 


\section{REFERENCES}

Antecol, Heather (2000), "An Examination of Cross-Country Differences in the Gender Gap in Labor Force Participation Rates”, Labour Economics 7, pp. 409-426.

Antecol, Heather, Deborah Cobb-Clark and Stephen Trejo (2002), "Human Capital and Earnings of Female Immigrants to Australia, Canada and the United States", Department of Economics, Claremont McKenna College, photocopy.

Baker, M. and Benjamin, D. (1997) "The Role of the Family in Immigrants' LaborMarket Activity: An Evaluation of Alternative Explanations," American Economic Review, 87, pp. 705-727.

Biswal, U.D. (1999) "Testing the Family "Common Preference” Model for Immigrant and Non-Immigrant Women's Labour Supply,” Canadian Public Policy, 25, pp. S95-S114.

Boyle, P., T.J. Cooke, K. Halfacree and D. Smith (2001) "A Cross-National Comparison of the Impact of Family Migration on Women's Employment Status," Demography, 38, pp. 201-213.

Chiswick, Barry R. (1978) "The Effect of Americanization on the Earnings of ForeignBorn Men,” Journal of Political Economy, 86(5), October, pp. 897-922.

Chiswick, Barry R. (1979) "The Economic Progress of Immigrants: Some Apparently Universal Patterns,” in William Fellner, ed., Contemporary Economic Problems, 1979, Washington: American Enterprise Institute, pp. 357-399.

Chiswick, Barry R. (1980) An Analysis of the Economic Progress and Impact of Immigrants, Prepared for the Employment and Training Administration, U.S. Department of Labor, National Technical Information Service, PB80-200454, August, 410 pp.

Chiswick, Barry R. (1986) "Human Capital and the Labor Market Adjustment of Immigrants: Testing Alternative Hypotheses," Research in Human Capital and Development, Vol. 4, pp. 1-26.

Chiswick, Barry R.(1998) "Hebrew Language Usage: Determinants and Effects on Earnings Among Immigrants in Israel", Journal of Population Economics Vol. 11, No.2, pp.253-271. 
Chiswick, Barry R. and Paul W. Miller (1995) "The Endogeneity Between Language and Earnings: International Analyses”, Journal of Labor Economics, Vol. 13, No.2, pp. 246-288.

Chiswick, Barry R. and Paul W. Miller (1998) "English Language Fluency Among Immigrants in the United States", Research in Labor Economics, Vol. 17, pp.151200

Cobb-Clark, Deborah. A. and M.D. Connolly (2001) "A Family Affair: The Labor Market Experience of Immigrant Spouses," Social Science Quarterly, 82, pp.796811.

Cobb-Clark, Deborah. A. and T.F. Crossley (2004) "Gender, Comparative Advantage and Labour Market Activity in Immigrant Families,” Journal of Labor Economics, forthcoming.

Duleep, Harriet and Seth Sanders (1993) "The Decision to Work by Married Immigrant Women: Evidence from Asian Women," Industrial and Labor Relations Review, 46(4), pp. 677-690.

Evans, M.D.R. (1984) "Immigrant Women in Australia: Resources, Family, and Work," International Migration Review, 18, pp. 1,063-1,090.

LeClere, F.B. and D.K. McLaughlin (1997) "Family Migration and Changes in Women's Earnings: A Decomposition Analysis,” Population Research and Policy Review, 16, pp. 315-335.

Long, James E. (1980) "The Effect of Americanization on Earnings: Some Evidence for Women,” Journal of Political Economy, 88(3), pp. 620-629.

MacPherson, D.A. and J.B. Stewart (1989) "The Labor Force Participation and Earnings Profiles of Married Female Immigrants," Quarterly Review of Economics and Business, 29, pp. 57-72.

Mincer, Jacob (1978) "Family Migration Decisions," Journal of Political Economy, 86(5), October, pp. 749-773.

Reimers, Cordelia W. (1985) "Cultural Differences in Labor Force Participation Among Married Women,” American Economic Review, 75, May, pp. 251-255. 
Table 1. Total number of individuals and foreigners in the ECHP sample by country.

\begin{tabular}{lllllll}
\hline $\begin{array}{l}\text { Country of } \\
\text { Destination }\end{array}$ & N. of Obs. & \% Total & $\begin{array}{l}\text { Number of } \\
\text { Foreigners }\end{array}$ & $\begin{array}{l}\text { \% Female } \\
\text { of Foreign }\end{array}$ & $\begin{array}{l}\text { \%Foreigners } \\
\text { EU born }\end{array}$ & $\begin{array}{l}\text { \% Foreign } \\
\text { in Country }\end{array}$ \\
\hline Germany & 67,422 & 12.3 & 6,571 & 38.1 & 39.26 & 9.75 \\
Denmark & 23,745 & 4.34 & 701 & 54.9 & 33.95 & 2.95 \\
Netherlands & 38,230 & 6.98 & 131 & 52.0 & 94.66 & 0.34 \\
Belgium & 22,257 & 4.06 & 1,629 & 38.0 & 56.11 & 7.32 \\
Luxembourg & 14,657 & 2.68 & 1,334 & 41.4 & 89.21 & 9.10 \\
France & 48,467 & 8.85 & 3,532 & 39.0 & 39.64 & 7.29 \\
United & & & & & & \\
Kingdom & 56,213 & 10.3 & 1,060 & 47.8 & 28.11 & 1.89 \\
Ireland & 27,882 & 5.09 & 1,309 & 42.2 & 87.78 & 4.69 \\
Italy & 52,952 & 9.67 & 1,067 & 42.7 & 35.71 & 2.02 \\
Greece & 32,866 & 6.00 & 1,372 & 35.8 & 86.95 & 4.17 \\
Spain & 44,403 & 8.11 & 782 & 47.6 & 39.00 & 1.76 \\
Portugal & 40,780 & 7.45 & 1,218 & 46.2 & 29.47 & 2.99 \\
Austria & 22,071 & 4.03 & 1,482 & 44.9 & 23.55 & 6.71 \\
Finland & 27,641 & 5.05 & 899 & 45.8 & 19.80 & 3.25 \\
Sweden & 28,053 & 5.12 & 2,558 & 46.7 & 44.49 & 9.12 \\
& & & & & & \\
Total & 547,639 & 100.0 & 28,053 & 43.2 & 46.0 & 5.12 \\
\hline
\end{tabular}

Note: Appendix A1 includes information on the shares of foreign-born in the data set used. However some information was missing for some covariates and the table above shows the sample that was used in the calculation.

Source: ECHP- Waves 1-7. 
Table 2. Simulated differences in earnings of foreigners at arrival, as percentage of the earnings of natives of the same gender.

\begin{tabular}{lcccccc}
\hline & $\begin{array}{c}\text { Foreign } \\
\text { Men }\end{array}$ & $\begin{array}{c}\text { Non-EU } \\
\text { Men }\end{array}$ & $\begin{array}{c}\text { Diff. } \\
\text { Eu/NonEU }\end{array}$ & $\begin{array}{c}\text { Foreign } \\
\text { Women }\end{array}$ & $\begin{array}{c}\text { Non-EU } \\
\text { Women }\end{array}$ & $\begin{array}{c}\text { Diff. } \\
\text { EU/NonEU }\end{array}$ \\
\hline Germany & $-0.153 \mathrm{a}$ & -0.181 & - & -0.017 & -0.112 & $\mathrm{~b}$ \\
Denmark & $-0.479 \mathrm{a}$ & -0.592 & - & $-0.362 \mathrm{a}$ & -0.461 & - \\
Netherlands & $-0.201 \mathrm{c}$ & -0.488 & - & $-0.342 \mathrm{a}$ & -0.037 & - \\
Belgium & $-0.204 \mathrm{a}$ & -0.459 & $\mathrm{a}$ & $-0.361 \mathrm{a}$ & -0.412 & - \\
Luxembourg & $-0.586 \mathrm{a}$ & -0.675 & - & $-0.537 \mathrm{a}$ & -0.693 & - \\
France & $-0.418 \mathrm{a}$ & -0.506 & $\mathrm{~b}$ & $-0.337 \mathrm{a}$ & -0.346 & - \\
United Kingdom & $-0.165 \mathrm{~b}$ & -0.539 & $\mathrm{a}$ & $-0.221 \mathrm{~b}$ & -0.383 & $\mathrm{c}$ \\
Ireland & $-0.528 \mathrm{a}$ & -0.326 & $\mathrm{~b}$ & $-0.415 \mathrm{a}$ & -1.141 & $\mathrm{a}$ \\
Italy & $-0.333 \mathrm{a}$ & -0.377 & - & $-0.517 \mathrm{a}$ & -0.492 & - \\
Greece & $-0.311 \mathrm{a}$ & -0.314 & - & $-0.484 \mathrm{a}$ & -0.499 & - \\
Spain & $-0.503 \mathrm{a}$ & -0.658 & $\mathrm{c}$ & $-0.311 \mathrm{a}$ & -0.569 & $\mathrm{~b}$ \\
Portugal & $-0.144 \mathrm{~b}$ & -0.192 & - & $-0.278 \mathrm{a}$ & -0.142 & - \\
Austria & $-0.307 \mathrm{a}$ & -0.409 & - & $-0.441 \mathrm{a}$ & -0.285 & $\mathrm{c}$ \\
Finland & $-0.613 \mathrm{a}$ & -0.462 & - & $-0.619 \mathrm{a}$ & -0.462 & - \\
Sweden & $-0.398 \mathrm{a}$ & -0.823 & $\mathrm{a}$ & $-0.500 \mathrm{a}$ & -0.701 & $\mathrm{a}$ \\
\hline & & & & & & \\
\hline
\end{tabular}

Note: Simulations are from estimates in Table 2A presented in Tables 3A and 4A in the Appendix. Earnings are calculated for an individual with 10 years of experience, high school diploma, married and with one child. For foreigners, earnings are measured at the time of arrival (Duration equal to zero years. For significance levels, foreigners are compared to natives and non-EU born to all foreigners. Significance margins: a) 1\%; b) 5\%; c) $10 \%$ and d) $15 \%$.

Source: ECHP- Waves 1-7. 
Table 3. Simulated differences in earnings of foreigners at arrival in different destination countries as compared to those arriving in Germany, by gender.

\begin{tabular}{lcccccc}
\hline Destination & \multicolumn{3}{c}{ Men } & & \multicolumn{3}{c}{ Women } \\
& Native & Foreign & Non-EU & Native & Foreign & Non-EU \\
& & & & & & \\
Germany & 0 & 0 & 0 & 0 & 0 & 0 \\
Denmark & -0.097 & -0.423 & -0.508 & 0.073 & -0.272 & -0.276 \\
Netherlands & 0.135 & 0.087 & -0.173 & -0.025 & -0.350 & 0.051 \\
Belgium & -0.039 & -0.090 & -0.316 & 0.066 & -0.278 & -0.233 \\
Luxembourg & 0.756 & 0.323 & 0.262 & 0.828 & 0.309 & 0.247 \\
France & -0.030 & -0.295 & -0.355 & 0.090 & -0.230 & -0.144 \\
United Kingdom & -0.017 & -0.028 & -0.375 & -0.072 & -0.276 & -0.343 \\
Ireland & 0.113 & -0.263 & -0.032 & 0.041 & -0.357 & -0.987 \\
Italy & -0.077 & -0.257 & -0.273 & 0.212 & -0.288 & -0.168 \\
Greece & -0.228 & -0.387 & -0.361 & -0.035 & -0.501 & -0.422 \\
Spain & -0.148 & -0.498 & -0.624 & -0.026 & -0.320 & -0.483 \\
Portugal & -0.384 & -0.376 & -0.395 & -0.102 & -0.364 & -0.133 \\
Austria & 0.139 & -0.015 & -0.089 & 0.202 & -0.222 & 0.029 \\
Finland & -0.207 & -0.667 & -0.489 & -0.066 & -0.668 & -0.416 \\
Sweden & -0.372 & -0.617 & -1.014 & -0.289 & -0.771 & -0.878 \\
& & & & & & \\
\hline
\end{tabular}

Note: Simulations are from estimates in Table A2 presented in Tables A3 and A4 in the Appendix. Earnings are calculated for an individual with 10 years of experience, high school diploma, married and with one child. For foreigners, earnings are measured at the time of arrival. Source: ECHP- Waves 1-7. 
Table 4. Selected variables from a regression analysis of earnings by gender.

\begin{tabular}{lcccc}
\hline & Women & Men & Women & Men \\
\hline & & & & \\
Less Secondary & -0.336 & -0.233 & -0.408 & -0.265 \\
Tertiary Educ. & $(61.26)$ & $(-56.4)$ & $(-65.4)$ & $(-58.1)$ \\
& 0.594 & 0.427 & 0.626 & 0.449 \\
Yrs.Experience & $(103.39)$ & $(93.1)$ & $(95.5)$ & $(87.2)$ \\
& 0.107 & 0.101 & 0.103 & 0.096 \\
Sq. Experience & $(163.14)$ & $(201.3)$ & $(135.7)$ & $(167.2)$ \\
& -0.002 & -0.002 & -0.002 & -0.002 \\
Years since Migr. & $(-150.96)$ & $(-202.1)$ & $(-123.6)$ & $(-167.9)$ \\
& 0.021 & 0.024 & 0.016 & 0.021 \\
Sq. YSM & $(8.43)$ & $(12.44)$ & $(5.7)$ & $(10.1)$ \\
& -0.00021 & -0.00031 & -0.00013 & -0.00028 \\
N. Children & $(-4.47)$ & $(-9.2)$ & $(-2.38)$ & $(-7.1)$ \\
& -0.144 & 0.008 & -0.115 & 0.005 \\
Marry & $(-61.54)$ & $(4.54)$ & $(-42.9)$ & $(2.8)$ \\
& 0.075 & 0.319 & 0.065 & 0.320 \\
Union & $(13.73)$ & $(64.22)$ & $(10.4)$ & $(57.1)$ \\
& 0.241 & 0.287 & 0.214 & 0.277 \\
Group Language*Foreign & $(30.90)$ & $(43.24)$ & $(22.5)$ & $(34.7)$ \\
& & & 0.112 & 0.146 \\
N.Obs & & & $(4.04)$ & $(6.4)$ \\
Adj.R-Sq. & & & \\
& 231,457 & 316,182 & 173,307 & 251,836 \\
\hline
\end{tabular}

Note: Dependent variable: natural logarithm of earnings. T-ratios are below coefficients. Complete estimates shown in Table A2 also include country dummy variables alone and interacted both with foreign origin and Non -EU origin. Language Information is not available for the Netherlands, the UK and Sweden, therefore these countries are not included in columns (3) and (4).

Source: ECHP- Waves 1-7. 
Table 5. Number of immigrants by continent of origin for each destination country.

\begin{tabular}{llllllll}
\hline Country & Asia & Oceania & Africa & America & $\begin{array}{l}\text { Non-Eng } \\
\text { Amer }\end{array}$ & $\begin{array}{l}\text { Eng } \\
\text { Amer }\end{array}$ & $\begin{array}{l}\text { No-EU } \\
\text { Europe }\end{array}$ \\
\hline Denmark & 320 & 4 & 64 & 105 & 70 & 35 & 298 \\
Belgium & 95 & & 706 & 97 & 83 & 14 & 590 \\
Luxembourg & 25 & & 80 & 24 & 9 & 15 & 1,318 \\
France & 390 & & 2,998 & 91 & 78 & 13 & 1,009 \\
United & & & & & & & \\
Kingdom & 618 & 75 & 262 & 215 & 125 & 90 & 261 \\
Ireland & 59 & 18 & 20 & 141 & 7 & 134 & 28 \\
Italy & 34 & 34 & 345 & 273 & 205 & 68 & 606 \\
Spain & 23 & 2 & 186 & 693 & 679 & 14 & 135 \\
Portugal & 20 & & 1,074 & 319 & 280 & 39 & 53 \\
Austria & 146 & & 28 & 54 & 27 & 27 & 1,987 \\
Sweden & 609 & 10 & 152 & 235 & 169 & 66 & 1,499 \\
& & & & & & & \\
Total & 2,339 & 143 & 5,915 & 2,247 & 1,732 & 515 & 7,784 \\
\hline
\end{tabular}

Note: Information on continents of origin is not available for Germany, the Netherlands, Greece or Finland. Source: ECHP- Waves 1-7. 
Table 6. Selected variables from regression analysis of earnings by continent of birth and country of destination, by gender.

\begin{tabular}{|c|c|c|c|c|}
\hline & Women & Men & Women & Men \\
\hline \multirow[t]{2}{*}{ Foreign } & -0.332 & -0.478 & & \\
\hline & $(-8.58)$ & $(-14.66)$ & & \\
\hline \multirow[t]{2}{*}{ Non-EU } & -0.157 & -0.124 & -0.211 & -0.181 \\
\hline & $(-4.72)$ & $(-4.34)$ & $(-5.64)$ & $(-5.51)$ \\
\hline \multirow[t]{2}{*}{ English America } & 0.103 & 0.061 & 0.136 & 0.110 \\
\hline & $(1.24)$ & $(0.73)$ & (1.59) & $(1.28)$ \\
\hline \multirow[t]{2}{*}{ No Eng. America } & -0.014 & -0.062 & 0.007 & -0.069 \\
\hline & $(-0.25)$ & $(-1.22)$ & $(0.11)$ & $(-1.25)$ \\
\hline \multirow[t]{2}{*}{ Asia } & 0.108 & -0.097 & 0.119 & -0.060 \\
\hline & $(2.08)$ & $(-2.22)$ & (2.18) & $(-1.29)$ \\
\hline \multirow[t]{2}{*}{ Africa } & 0.301 & 0.070 & 0.259 & 0.030 \\
\hline & (7.38) & $(2.15)$ & $(5.44)$ & $(0.79)$ \\
\hline \multirow[t]{2}{*}{ Oceania } & 0.351 & 0.574 & 0.326 & 0.583 \\
\hline & (1.89) & $(4.95)$ & $(1.71)$ & $(4.92)$ \\
\hline \multicolumn{2}{|l|}{ Germany*F } & & N/A & N/A \\
\hline \multirow[t]{2}{*}{ Denmark*F } & & & -0.243 & -0.466 \\
\hline & & & $(-3.47)$ & $(-7.61)$ \\
\hline \multicolumn{2}{|l|}{ Netherlands*F } & & N/A & N/A \\
\hline \multirow[t]{2}{*}{ Belgium*F } & & & -0.264 & -0.277 \\
\hline & & & $(-4.67)$ & $(-5.87)$ \\
\hline \multirow[t]{2}{*}{ Luxembourg*F } & & & -0.484 & -0.607 \\
\hline & & & $(-9.0)$ & $(-14.2)$ \\
\hline \multirow[t]{2}{*}{ France*F } & & & -0.232 & -0.406 \\
\hline & & & $(-4.58)$ & $(-9.45)$ \\
\hline \multirow[t]{2}{*}{ United Kingdom*F } & & & -0.200 & -0.359 \\
\hline & & & $(-3.13)$ & $(-6.46)$ \\
\hline \multirow[t]{2}{*}{ Ireland*F } & & & -0.387 & -0.533 \\
\hline & & & $(-6.81)$ & $(-11.03)$ \\
\hline \multirow[t]{2}{*}{ Italy*F } & & & -0.323 & -0.309 \\
\hline & & & $(-5.18)$ & $(-5.76)$ \\
\hline \multicolumn{2}{|l|}{ Greece*F } & & N/A & N/A \\
\hline \multirow[t]{2}{*}{ Spain*F } & & & -0.297 & -0.511 \\
\hline & & & $(-4.21)$ & $(-8.92)$ \\
\hline \multirow[t]{2}{*}{ Portugal*F } & & & -0.104 & -0.102 \\
\hline & & & $(-1.68)$ & $(-2.01)$ \\
\hline \multirow[t]{2}{*}{ Austria*F } & & & -0.107 & $-0.276)$ \\
\hline & & & $(-1.84)$ & $(-5.43)$ \\
\hline Finland*F & & & N/A & N/A \\
\hline
\end{tabular}


N.Obs

160466

221014

160466

221014

Adj.R-Sq.

0.986

0.989

0.986

0.989

Note: Dependent variable: natural logarithm of earnings. T-ratios are below coefficients. Complete estimates also include country of destination dummy variables as well as individual characteristics. Information on continents is not available for Germany, the Netherlands, Greece and Finland; therefore these countries are not included in the sample. * F indicates foreign born living in that country.

Source: ECHP- Waves 1-7. 


\section{Appendix}

Table A1 Sample available if variable years since migration was not included.

\begin{tabular}{lcccc}
\hline Country & Observations & \% Total & $\begin{array}{c}\text { Foreign in } \\
\text { Country }\end{array}$ & $\begin{array}{c}\text { \% Foreign in } \\
\text { Country }\end{array}$ \\
\hline Germany & & & & \\
Denmark & 69,597 & 12.45 & 8,746 & 12.57 \\
Netherlands & 23,859 & 4.27 & 815 & 3.42 \\
Belgium & 38,583 & 6.9 & 484 & 1.25 \\
Luxembourg & 22,795 & 4.08 & 2,167 & 9.51 \\
France & 21,301 & 3.81 & 7,978 & 37.45 \\
United Kingdom & 48,838 & 8.74 & 3,903 & 7.99 \\
Ireland & 56,979 & 10.19 & 1,826 & 3.20 \\
Italy & 27,891 & 4.99 & 1,318 & 4.73 \\
Greece & 52,986 & 9.48 & 1,101 & 2.08 \\
Spain & 32,955 & 5.89 & 1,461 & 4.43 \\
Portugal & 44,443 & 7.95 & 822 & 1.85 \\
Austria & 40,964 & 7.33 & 1,402 & 3.42 \\
Finland & 22,138 & 3.96 & 1,549 & 7.00 \\
Sweden & 27,708 & 4.96 & 966 & 3.49 \\
Total & 28,069 & 5.02 & 2,574 & 9.17 \\
\hline
\end{tabular}

Proportion of European Union citizens among migrants

\begin{tabular}{lcc}
\hline Country & \% EU born in ECHP & \% EU born in sample \\
\hline Germany & 38.39 & 39.26 \\
Denmark & 41.45 & 33.95 \\
Netherlands & 61.26 & 94.66 \\
Belgium & 65.19 & 56.11 \\
Luxembourg & 88.23 & 89.21 \\
France & 39.58 & 39.64 \\
United Kingdom & 52.16 & 28.11 \\
Ireland & 87.7 & 87.78 \\
Italy & 37.97 & 35.71 \\
Greece & 90.79 & 86.95 \\
Spain & 43.01 & 39.00 \\
Portugal & 39.65 & 29.47 \\
Austria & 25.62 & 23.55 \\
Finland & 25.83 & 19.8 \\
Sweden & 39.38 & 44.49 \\
& & \\
Total & 55 & 46 \\
\hline
\end{tabular}

Source: ECHP- Waves 1-7. 
Table A2. Regression analysis of earnings with country interacted both with foreign origin and Non-EU birth, by gender.

\begin{tabular}{|c|c|c|c|c|}
\hline & Women & Men & Women & Men \\
\hline Less Secondary & $\begin{array}{c}-0.336 \\
(61.26)\end{array}$ & $\begin{array}{l}-0.233 \\
(-56.4)\end{array}$ & $\begin{array}{l}-0.408 \\
(-65.4)\end{array}$ & $\begin{array}{l}-0.265 \\
(-58.1)\end{array}$ \\
\hline Tertiary Educ. & $\begin{array}{c}0.594 \\
(103.39)\end{array}$ & $\begin{array}{l}0.427 \\
(93.1)\end{array}$ & $\begin{array}{l}0.626 \\
(95.5)\end{array}$ & $\begin{array}{l}0.449 \\
(87.2)\end{array}$ \\
\hline Yrs.Experience & $\begin{array}{c}0.107 \\
(163.14)\end{array}$ & $\begin{array}{c}0.101 \\
(201.3)\end{array}$ & $\begin{array}{c}0.103 \\
(135.7)\end{array}$ & $\begin{array}{c}0.096 \\
(167.2)\end{array}$ \\
\hline Sq. Experience & $\begin{array}{c}-0.002 \\
(-150.96)\end{array}$ & $\begin{array}{c}-0.002 \\
(-202.1)\end{array}$ & $\begin{array}{c}-0.002 \\
(-123.6)\end{array}$ & $\begin{array}{c}-0.002 \\
(-167.9)\end{array}$ \\
\hline Years since Migr. & $\begin{array}{l}0.021 \\
(8.43)\end{array}$ & $\begin{array}{c}0.024 \\
(12.44)\end{array}$ & $\begin{array}{c}0.016 \\
(5.7)\end{array}$ & $\begin{array}{l}0.021 \\
(10.1)\end{array}$ \\
\hline Sq. YSM & $\begin{array}{c}-0.00021 \\
(-4.47)\end{array}$ & $\begin{array}{c}-0.00031 \\
(-9.2)\end{array}$ & $\begin{array}{c}-0.00013 \\
(-2.38)\end{array}$ & $\begin{array}{c}-0.00028 \\
(-7.1)\end{array}$ \\
\hline N. Children & $\begin{array}{c}-0.144 \\
(-61.54)\end{array}$ & $\begin{array}{l}0.008 \\
(4.54)\end{array}$ & $\begin{array}{l}-0.115 \\
(-42.9)\end{array}$ & $\begin{array}{c}0.005 \\
(2.8)\end{array}$ \\
\hline Marry & $\begin{array}{c}0.075 \\
(13.73)\end{array}$ & $\begin{array}{c}0.319 \\
(64.22)\end{array}$ & $\begin{array}{l}0.065 \\
(10.4)\end{array}$ & $\begin{array}{l}0.320 \\
(57.1)\end{array}$ \\
\hline Union & $\begin{array}{c}0.241 \\
(30.90)\end{array}$ & $\begin{array}{c}0.287 \\
(43.24)\end{array}$ & $\begin{array}{l}0.214 \\
(22.5)\end{array}$ & $\begin{array}{l}0.277 \\
(34.7)\end{array}$ \\
\hline Group Language & & & $\begin{array}{l}0.112 \\
(4.04)\end{array}$ & $\begin{array}{c}0.146 \\
(6.4)\end{array}$ \\
\hline Germany*F & $\begin{array}{l}-0.017 \\
(-0.36)\end{array}$ & $\begin{array}{l}-0.153 \\
(-4.28)\end{array}$ & $\begin{array}{l}0.071 \\
(1.41)\end{array}$ & $\begin{array}{l}-0.104 \\
(-2.8)\end{array}$ \\
\hline Denmark*F & $\begin{array}{l}-0.362 \\
(-3.41)\end{array}$ & $\begin{array}{l}-0.479 \\
(-5.77)\end{array}$ & $\begin{array}{c}-0.370 \\
(-3.5)\end{array}$ & $\begin{array}{l}-0.478 \\
(-5.8)\end{array}$ \\
\hline Netherlands*F & $\begin{array}{l}-0.342 \\
(-2.54)\end{array}$ & $\begin{array}{l}-0.201 \\
(-1.69)\end{array}$ & N/A & N/A \\
\hline Belgium*F & $\begin{array}{l}-0.361 \\
(-6.04)\end{array}$ & $\begin{array}{l}-0.204 \\
(-4.15)\end{array}$ & $\begin{array}{c}-0.378 \\
(-6.1)\end{array}$ & $\begin{array}{l}-0.266 \\
(-5.24)\end{array}$ \\
\hline Luxembourg*F & $\begin{array}{l}-0.537 \\
(-9.87)\end{array}$ & $\begin{array}{c}-0.586 \\
(-14.29)\end{array}$ & $\begin{array}{c}-0.489 \\
(-8.9)\end{array}$ & $\begin{array}{l}-0.549 \\
(-13.3)\end{array}$ \\
\hline France*F & $\begin{array}{l}-0.337 \\
(-6.24)\end{array}$ & $\begin{array}{l}-0.418 \\
(-9.78)\end{array}$ & $\begin{array}{c}-0.333 \\
(-5.9)\end{array}$ & $\begin{array}{l}-0.470 \\
(-10.5)\end{array}$ \\
\hline United Kingdom*F & $\begin{array}{l}-0.221 \\
(-2.50)\end{array}$ & $\begin{array}{l}-0.165 \\
(-2.04)\end{array}$ & N/A & N/A \\
\hline Ireland*F & $\begin{array}{l}-0.415 \\
(-7.59)\end{array}$ & $\begin{array}{c}-0.528 \\
(-11.62)\end{array}$ & $\begin{array}{c}-0.411 \\
(-7.3)\end{array}$ & $\begin{array}{l}-0.554 \\
(-12.0)\end{array}$ \\
\hline Italy*F & $\begin{array}{l}-0.517 \\
(-6.42)\end{array}$ & $\begin{array}{l}-0.333 \\
(-4.61)\end{array}$ & $\begin{array}{l}-0.519 \\
(-6.4)\end{array}$ & $\begin{array}{l}-0.401 \\
(-5.5)\end{array}$ \\
\hline Greece*F $^{*}$ & $\begin{array}{l}-0.484 \\
(-9.02)\end{array}$ & $\begin{array}{l}-0.311 \\
(-7.36)\end{array}$ & $\begin{array}{c}-0.496 \\
(-8.9)\end{array}$ & $\begin{array}{l}-0.385 \\
(-8.7)\end{array}$ \\
\hline
\end{tabular}




\begin{tabular}{|c|c|c|c|c|}
\hline Spain*F & $\begin{array}{l}-0.311 \\
(-3.16)\end{array}$ & $\begin{array}{l}-0.503 \\
(-6.99)\end{array}$ & $\begin{array}{l}-0.307 \\
(-3.12)\end{array}$ & $\begin{array}{c}-0.556 \\
(-7.7)\end{array}$ \\
\hline Portugal*F & $\begin{array}{l}-0.278 \\
(-3.26)\end{array}$ & $\begin{array}{l}-0.144 \\
(-2.08)\end{array}$ & $\begin{array}{l}-0.310 \\
(-3.57)\end{array}$ & $\begin{array}{l}-0.235 \\
(-3.35)\end{array}$ \\
\hline Austria*F & $\begin{array}{l}-0.441 \\
(-5.39)\end{array}$ & $\begin{array}{l}-0.307 \\
(-3.98)\end{array}$ & $\begin{array}{l}-0.480 \\
(-5.84)\end{array}$ & $\begin{array}{l}-0.387 \\
(-5.0)\end{array}$ \\
\hline Finland*F & $\begin{array}{l}-0.619 \\
(-4.67)\end{array}$ & $\begin{array}{l}-0.613 \\
(-6.90)\end{array}$ & $\begin{array}{l}-0.586 \\
(-4.47)\end{array}$ & $\begin{array}{l}-0.631 \\
(-7.18)\end{array}$ \\
\hline Sweden*F & $\begin{array}{l}-0.500 \\
(-9.22)\end{array}$ & $\begin{array}{l}-0.398 \\
(-8.38)\end{array}$ & N/A & N/A \\
\hline Germany*No-EU & $\begin{array}{l}-0.095 \\
(-2.23)\end{array}$ & $\begin{array}{l}-0.028 \\
(-0.95)\end{array}$ & $\begin{array}{l}-0.095 \\
(-2.26)\end{array}$ & $\begin{array}{l}-0.033 \\
(-1.11)\end{array}$ \\
\hline Denmark*No-EU & $\begin{array}{l}-0.099 \\
(-0.83)\end{array}$ & $\begin{array}{l}-0.113 \\
(-1.11)\end{array}$ & $\begin{array}{c}-0.058 \\
(-0.5)\end{array}$ & $\begin{array}{l}-0.096 \\
(-0.95)\end{array}$ \\
\hline Netherlands*No-EU & $\begin{array}{l}0.306 \\
(0.50)\end{array}$ & $\begin{array}{l}-0.288 \\
(-0.61)\end{array}$ & N/A & N/A \\
\hline Belgium*No-EU & $\begin{array}{l}-0.050 \\
(-0.62)\end{array}$ & $\begin{array}{l}-0.255 \\
(-4.23)\end{array}$ & $\begin{array}{l}-0.019 \\
(-0.24)\end{array}$ & $\begin{array}{l}-0.231 \\
(-3.89)\end{array}$ \\
\hline Luxembourg*No-EU & $\begin{array}{l}-0.157 \\
(-1.21)\end{array}$ & $\begin{array}{l}-0.089 \\
(-0.78)\end{array}$ & $\begin{array}{l}-0.166 \\
(-1.30)\end{array}$ & $\begin{array}{l}-0.103 \\
(-0.91)\end{array}$ \\
\hline France*No-EU & $\begin{array}{l}-0.010 \\
(-0.17)\end{array}$ & $\begin{array}{l}-0.088 \\
(-2.12)\end{array}$ & $\begin{array}{l}-0.010 \\
(-0.18)\end{array}$ & $\begin{array}{l}-0.057 \\
(-1.39)\end{array}$ \\
\hline United Kingdom*No-EU & $\begin{array}{l}-0.162 \\
(-1.63)\end{array}$ & $\begin{array}{l}-0.374 \\
(-4.18)\end{array}$ & N/A & N/A \\
\hline Ireland*No-EU & $\begin{array}{l}-0.725 \\
(-5.47)\end{array}$ & $\begin{array}{l}0.203 \\
(1.96)\end{array}$ & $\begin{array}{c}-0.740 \\
(-5.7)\end{array}$ & $\begin{array}{l}0.202 \\
(1.98)\end{array}$ \\
\hline Italy*No-EU & $\begin{array}{l}0.025 \\
(0.26)\end{array}$ & $\begin{array}{l}-0.044 \\
(-0.54)\end{array}$ & $\begin{array}{l}0.015 \\
(0.16)\end{array}$ & $\begin{array}{l}-0.020 \\
(-0.24)\end{array}$ \\
\hline Greece*No-EU & $\begin{array}{l}-0.015 \\
(-0.11)\end{array}$ & $\begin{array}{l}-0.002 \\
(-0.03)\end{array}$ & $\begin{array}{l}-0.026 \\
(-0.19)\end{array}$ & $\begin{array}{l}0.020 \\
(0.22)\end{array}$ \\
\hline Spain*No-EU & $\begin{array}{l}-0.258 \\
(-2.23)\end{array}$ & $\begin{array}{l}-0.154 \\
(-1.72)\end{array}$ & $\begin{array}{l}-0.288 \\
(-2.53)\end{array}$ & $\begin{array}{l}-0.145 \\
(-1.65)\end{array}$ \\
\hline Portugal*No-EU & $\begin{array}{l}0.136 \\
(1.42)\end{array}$ & $\begin{array}{l}-0.047 \\
(-0.60)\end{array}$ & $\begin{array}{l}0.122 \\
(1.3)\end{array}$ & $\begin{array}{l}-0.046 \\
(-0.6)\end{array}$ \\
\hline Austria*No-EU & $\begin{array}{l}0.156 \\
(1.76)\end{array}$ & $\begin{array}{l}-0.102 \\
(-1.24)\end{array}$ & $\begin{array}{l}0.220 \\
(2.5)\end{array}$ & $\begin{array}{l}-0.014 \\
(-0.18)\end{array}$ \\
\hline Finland*No-EU & $\begin{array}{l}0.157 \\
(1.11)\end{array}$ & $\begin{array}{l}0.151 \\
(1.5)\end{array}$ & $\begin{array}{l}0.109 \\
(0.8)\end{array}$ & $\begin{array}{l}0.132 \\
(1.37)\end{array}$ \\
\hline Sweden*No-EU & $\begin{array}{l}-0.202 \\
(-3.41)\end{array}$ & $\begin{array}{l}-0.425 \\
(-8.01)\end{array}$ & N/A & N/A \\
\hline Germany & $\begin{array}{c}7.731 \\
(841.7)\end{array}$ & $\begin{array}{c}8.049 \\
(1092.5)\end{array}$ & $\begin{array}{c}7.742 \\
(782.5)\end{array}$ & $\begin{array}{c}8.101 \\
(1033.7)\end{array}$ \\
\hline Denmark & $\begin{array}{c}7.804 \\
(647.1)\end{array}$ & $\begin{array}{c}7.952 \\
(797.7)\end{array}$ & $\begin{array}{c}7.811 \\
(622.1) \\
\end{array}$ & $\begin{array}{c}8.002 \\
(778.8)\end{array}$ \\
\hline
\end{tabular}




\begin{tabular}{|c|c|c|c|c|}
\hline Netherlands & $\begin{array}{c}7.706 \\
(723.1)\end{array}$ & $\begin{array}{c}8.184 \\
(955.7)\end{array}$ & N/A & N/A \\
\hline Belgium & $\begin{array}{c}7.797 \\
(615.3)\end{array}$ & $\begin{array}{c}8.010 \\
(778.1)\end{array}$ & $\begin{array}{c}7.794 \\
(595.4)\end{array}$ & $\begin{array}{c}8.064 \\
(762.7)\end{array}$ \\
\hline Luxembourg & $\begin{array}{c}8.559 \\
(518.0)\end{array}$ & $\begin{array}{c}8.805 \\
(784.6)\end{array}$ & $\begin{array}{c}8.590 \\
(514.5)\end{array}$ & $\begin{array}{c}8.863 \\
(774.8)\end{array}$ \\
\hline France & $\begin{array}{c}7.821 \\
(785.7)\end{array}$ & $\begin{array}{c}8.019 \\
(996.1)\end{array}$ & $\begin{array}{c}7.834 \\
(739.2)\end{array}$ & $\begin{array}{c}8.079 \\
(953.3)\end{array}$ \\
\hline United Kingdom & $\begin{array}{c}7.659 \\
(812.1)\end{array}$ & $\begin{array}{c}8.032 \\
(1028.4)\end{array}$ & N/A & N/A \\
\hline Ireland & $\begin{array}{c}7.772 \\
(662.0)\end{array}$ & $\begin{array}{c}8.162 \\
(942.8)\end{array}$ & $\begin{array}{c}7.773 \\
(648.2)\end{array}$ & $\begin{array}{c}8.213 \\
(922.3)\end{array}$ \\
\hline Italy & $\begin{array}{c}7.943 \\
(788.8)\end{array}$ & $\begin{array}{c}7.972 \\
(1055.5)\end{array}$ & $\begin{array}{c}7.963 \\
(746.7)\end{array}$ & $\begin{array}{c}8.038 \\
(1001.6)\end{array}$ \\
\hline Greece & $\begin{array}{c}7.696 \\
(629.1)\end{array}$ & $\begin{array}{c}7.821 \\
(927.1)\end{array}$ & $\begin{array}{c}7.703 \\
(610.0)\end{array}$ & $\begin{array}{c}7.877 \\
(892.5)\end{array}$ \\
\hline Spain & $\begin{array}{c}7.705 \\
(719.9)\end{array}$ & $\begin{array}{c}7.901 \\
(1009.8)\end{array}$ & $\begin{array}{c}7.722 \\
(689.0)\end{array}$ & $\begin{array}{c}7.965 \\
(965.0)\end{array}$ \\
\hline Portugal & $\begin{array}{c}7.629 \\
(695.2)\end{array}$ & $\begin{array}{c}7.665 \\
(916.0)\end{array}$ & $\begin{array}{c}7.664 \\
(662.4)\end{array}$ & $\begin{array}{c}7.733 \\
(878.5)\end{array}$ \\
\hline Austria & $\begin{array}{c}7.933 \\
(614.9)\end{array}$ & $\begin{array}{c}8.188 \\
(849.4)\end{array}$ & $\begin{array}{c}7.948 \\
(601.8)\end{array}$ & $\begin{array}{c}8.244 \\
(835.2)\end{array}$ \\
\hline Finland & $\begin{array}{c}7.665 \\
(675.3)\end{array}$ & $\begin{array}{c}7.842 \\
(829.6)\end{array}$ & $\begin{array}{c}7.665 \\
(646.1)\end{array}$ & $\begin{array}{c}7.892 \\
(810.0)\end{array}$ \\
\hline Sweden & $\begin{array}{c}7.442 \\
(639.9)\end{array}$ & $\begin{array}{c}7.677 \\
(786.9)\end{array}$ & N/A & N/A \\
\hline $\begin{array}{l}\text { N.Obs } \\
\text { Adj.R-Sq. }\end{array}$ & $\begin{array}{r}231457 \\
0.9864\end{array}$ & $\begin{array}{c}316182 \\
0.9903\end{array}$ & $\begin{array}{c}173307 \\
0.987\end{array}$ & $\begin{array}{r}251836 \\
0.9905\end{array}$ \\
\hline
\end{tabular}

Note: Dependent variable: natural logarithm of earnings. T-ratios are below coefficients.

Language Information is not available for the Netherlands, UK and Sweden. Therefore these countries are not included in columns (3) and (4). *F and *No-EU indicate foreign born and born outside the EU individuals living in that country.

Source: ECHP- Waves 1-7. 
Table A3 Simulated natural logarithm of earnings at arrival for Women: Natives, Foreigners and Non-EU Foreigners.

\begin{tabular}{|c|c|c|c|}
\hline & Native & Foreign & Non-EU \\
\hline Germany & 7.731 & 7.714 & 7.619 \\
\hline Denmark & 7.804 & 7.442 & 7.343 \\
\hline Netherlands & 7.706 & 7.364 & 7.670 \\
\hline Belgium & 7.797 & 7.436 & 7.386 \\
\hline Luxembourg & 8.559 & 8.023 & 7.866 \\
\hline France & 7.821 & 7.484 & 7.475 \\
\hline United Kingdom & 7.659 & 7.438 & 7.276 \\
\hline Ireland & 7.772 & 7.357 & 6.632 \\
\hline Italy & 7.943 & 7.426 & 7.451 \\
\hline Greece & 7.696 & 7.213 & 7.197 \\
\hline Spain & 7.705 & 7.394 & 7.136 \\
\hline Portugal & 7.629 & 7.350 & 7.486 \\
\hline Austria & 7.933 & 7.492 & 7.648 \\
\hline Finland & 7.665 & 7.046 & 7.203 \\
\hline Sweden & 7.442 & 6.943 & 6.741 \\
\hline
\end{tabular}

Note: Simulations from estimates in Table A2 considering an individual with 10 years of experience, high school diploma, married and with one child. For foreigners, earnings are measured at the time of arrival (Duration equals zero).

Source: ECHP- Waves 1-7. 
Table A4 Simulated natural logarithm of earnings for Men: Natives, Foreigners and NonEU Foreigners.

\begin{tabular}{llll}
\hline & Native & Foreign & Non-EU \\
\hline & & & \\
Germany & 8.049 & 7.896 & 7.868 \\
Denmark & 7.952 & 7.473 & 7.360 \\
Netherlands & 8.184 & 7.983 & 7.695 \\
Belgium & 8.010 & 7.806 & 7.552 \\
Luxembourg & 8.805 & 8.219 & 8.130 \\
France & 8.019 & 7.601 & 7.513 \\
United Kingdom & 8.032 & 7.868 & 7.493 \\
Ireland & 8.162 & 7.633 & 7.836 \\
Italy & 7.972 & 7.639 & 7.595 \\
Greece & 7.821 & 7.509 & 7.507 \\
Spain & 7.901 & 7.398 & 7.244 \\
Portugal & 7.665 & 7.520 & 7.473 \\
Austria & 8.188 & 7.881 & 7.779 \\
Finland & 7.842 & 7.229 & 7.379 \\
Sweden & 7.677 & 7.279 & 6.854 \\
\hline
\end{tabular}

Note: Simulations from estimates in Table A2 considering an individual with 10 years of experience, high school diploma, married and with one child. For foreigners, earnings are measured at the time of arrival (Duration equals zero).

Source: ECHP- Waves 1-7. 
Table A5. Proportion of immigrants with group language match.

\begin{tabular}{lc}
\hline Country & $\begin{array}{c}\text { Group } \\
\text { Language }\end{array}$ \\
\hline Germany & 13.0 \\
Denmark & 27.7 \\
Netherlands & N/A \\
Belgium & 52.9 \\
Luxembourg & 48.4 \\
France & 44.7 \\
United Kingdom & N/A \\
Ireland & 44.6 \\
Italy & 57.1 \\
Greece & 58.2 \\
Spain & 52.4 \\
Portugal & 73.9 \\
Austria & 36.0 \\
Finland & 38.8 \\
Sweden & N/A \\
& \\
Total & 40.1 \\
\hline
\end{tabular}

Note: Group Language=1 when the linguistic group of the language from the country and the migrant's match. See text for details. 
Table A6. Share of immigrants across continents.

\begin{tabular}{lccccccc}
\hline Country & Asia & Oceania & Africa & America & $\begin{array}{c}\text { Non-Eng } \\
\text { Amer }\end{array}$ & $\begin{array}{c}\text { Eng } \\
\text { Emer Non-EU } \\
\text { Europe }\end{array}$ \\
& & & & & & & \\
Denmark & 13.7 & 2.8 & 1.1 & 4.7 & 4.0 & 6.8 & 3.8 \\
Belgium & 4.1 & & 11.9 & 4.3 & 4.8 & 2.7 & 7.6 \\
Luxembourg & 1.1 & & 1.4 & 1.1 & 0.5 & 2.9 & 16.9 \\
France & 16.7 & & 50.7 & 4.0 & 4.5 & 2.5 & 13.0 \\
United & & 52.4 & & & & & \\
Kingdom & 26.4 & & 4.4 & 9.6 & 7.2 & 17.5 & 3.4 \\
Ireland & 2.5 & 12.6 & 0.3 & 6.3 & 0.4 & 26.0 & 0.4 \\
Italy & 1.5 & 23.8 & 5.8 & 12.1 & 11.8 & 13.2 & 7.8 \\
Spain & 1.0 & 1.4 & 3.1 & 30.8 & 39.2 & 2.7 & 1.7 \\
Portugal & 0.9 & & 18.2 & 14.2 & 16.2 & 7.6 & 0.7 \\
Austria & 6.2 & & 0.5 & 2.4 & 1.6 & 5.2 & 25.5 \\
Sweden & 26.0 & 7.0 & 2.6 & 10.5 & 9.8 & 12.8 & 19.3 \\
& & & & & & & 100.3 \\
Total & 100.0 & 100.0 & 100.0 & 100.0 & 100.0 & 100.0 & 100.0 \\
\hline
\end{tabular}

Note: Information on continents of origin is not available for Germany, Netherlands, Greece or Finland. Source: ECHP- Waves 1-7. 